\title{
Immobilization of phosphorus in sewage sludge using inorganic amendments
}

\author{
Zhen Liang $\cdot$ Xianjia Peng $\cdot$ Jun Wang \\ Zhaokun Luan $\cdot$ Zhimei Liu $\cdot$ Yunxia Wang
}

Received: 17 November 2009/Accepted: 10 July 2010/Published online: 27 July 2010

(C) Springer-Verlag 2010

\begin{abstract}
Sewage sludge contains large amount of watersoluble phosphorus, which is prone to runoff loss when sewage sludge is land applied. Phosphorus export from sewage sludge is an important cause for water eutrophication. Immobilization of phosphorus before sewage sludge land application seems necessary. In this study, three amendments including red mud (RM), lime and mixture of RM and lime were employed to immobilize phosphorus in fresh sewage sludge. It was found that phosphorus was effectively controlled by RM, lime and mixture of RM and lime. Sequential chemical extraction results indicate that the $\mathrm{RM}$ amendment transformed $\mathrm{H}_{2} \mathrm{O}-\mathrm{P}$ in the sewage sludge into the NaOH-P, while the lime amendment transformed $\mathrm{H}_{2} \mathrm{O}-\mathrm{P}$ in the sewage sludge into the $\mathrm{HCl}-\mathrm{P}$. Such transformations in phosphorus fractions would have little influence on phosphorus availability but would retard and reduce potential phosphorus loss following sewage sludge was land applied.
\end{abstract}

Keywords Sewage sludge $\cdot$ Red mud $\cdot$ Lime · Phosphorus

Z. Liang $\cdot$ X. Peng $(\bowtie) \cdot J$. Wang $\cdot$ Z. Luan

State Key Laboratory of Environmental Aquatic Chemistry, Research Center for Eco-Environmental Sciences,

Chinese Academy of Sciences, P.O. Box 2871,

Beijing 100085, People's Republic of China

e-mail: xjpeng@rcees.ac.cn

Z. Liang

e-mail: Liangzh2004@163.com

Z. Liu $\cdot$ Y. Wang

School of Chemical and Environmental Engineering,

China University of Mining and Technology,

Beijing 100083, People's Republic of China

\section{Introduction}

Population growth and urbanization resulted in generation of large amount of sewage. Sewage sludge is an inevitable end byproduct of sewage treatment. Treatment and disposal of sewage sludge are the most costly phase of sewage treatment (Huang et al. 2008b). It is reported that over 1.47 million tons of dewatered sewage sludge was produced in China in 2007 (Wang W et al. 2010), and the production is predicted to increase to 3.60 million tons in 2010 (Lee et al. 2006). The accumulation of sewage sludge from sewage treatment plants is of increasing concern.

The disposal methods of sewage sludge include landfill, incineration, dumping and land application (Zheng et al. 2006; Matthews 1992). Landfill may cause ground water contamination due to its leaching. Incineration is unpopular because of the high cost and environmental hazards involved. Dumping at sea has been prohibited in many countries including China. Land application of sewage sludge has become more popular because of the relative low cost and potential benefits of recycling plant nutrients and organic matter, as well as improving the physical properties and agricultural productivity of soils (Clapp et al. 1994).

Despite the relative low cost and the potential benefits, there is still concern about land application of sewage sludge. Ratios of nitrogen to phosphorus in sewage sludge are usually narrower than that required for crop growth (O'Connor et al. 2004). Land application of sewage sludge based on the nitrogen requirements of crops generally results in excessive phosphorus accumulation in soils. The excessive phosphorus accumulation in soils is not harmful to crops but could lead to phosphorus loss to ground water and contribute to eutrophication of ground water (Peterson et al. 1994; Correll 1998). 
There are many methods to control phosphorus loss. A promising method is the addition of chemical amendments. Soluble phosphorus in sewage sludge solution can react with aluminum $(\mathrm{Al})$, iron $(\mathrm{Fe})$ and calcium $(\mathrm{Ca})$ to form insoluble phosphorus. Previous studies have shown that addition of materials containing these elements can reduce phosphorus solubility (Dou et al. 2003; Stout et al. 2000; Kalbasi and Karthikeyan 2004). A large number of different amendments have been proposed and tested for immobilization of phosphorus in sewage sludge and manures. It has been confirmed that ferrous sulfate, aluminum sulfate, calcium oxide, calcium carbonate, gypsum and nanoscale zero-valent iron were effective for immobilization of phosphorus in sewage sludge and manures for land application (Huang et al. 2007, 2008b; Huang and Shenker 2004; Logan and Burnham 1995a, b; Moore and Miller 1994; Li et al. 2007; Ippolito et al. 2003; Mahdy et al. 2009). Although some of these materials and techniques have been studied in laboratory, greenhouse and field, their continual use could depend on the cost and availability of the materials. Thus, there is an increasing need for cost-effective alternative amendment to reduce phosphorus loss.

Red mud (RM) is an industrial byproduct of bauxite with sodium hydroxide during aluminum extraction. Because of its relatively large surface area and high content of iron, aluminum, calcium, silica, titanium oxides and hydroxides, RM can be considered as a cost-effective material for phosphorus adsorption. A number of studies have shown that RM can be used for phosphorus removal from aqueous solutions (Roberge et al. 1999; Li et al. 2006; Liu et al. 2007; Huang et al. 2008a; Zhao et al. 2009). Further, Summers et al. showed that application of RM to soils can be very effective in increasing phosphorus retention in sandy soil catchments, reducing phosphorus leaching from sandy soils and improving pasture growth on sandy soils (Summers et al. 1993, 1996a, b; Vlahos et al. 1989).

Although the immobilization of phosphorus using RM amendment in soils has been successfully demonstrated in many studies (Summers et al. 1993, 1996a, b; Vlahos et al. 1989; Ho et al. 1989; McPharlin et al. 1994; Udeigwe et al. 2009; Anderson et al. 1995), there have been few reports on the investigation of immobilization of phosphorus in sewage sludge by RM. The objective of this study was to investigate the efficacy of RM to immobilize phosphorus in sewage sludge compared with that in lime and mixture of $\mathrm{RM}$ and lime $(\mathrm{RM} /$ lime $=2: 1, \mathrm{w} / \mathrm{w})$ amended sewage sludge. The utilization of RM for sewage sludge immobilization may substitute lime and minimize the costs of lime purchasing and landfilling. In addition, leaching experiments were conducted to evaluate the efficiency of RM, lime and RM/lime to immobilize phosphorus in sewage sludge. Furthermore, sequential chemical extraction experiments were conducted to explain the mechanisms of immobilization of phosphorus in sewage sludge.

\section{Materials and methods}

\section{Materials}

Sewage sludge was obtained from Xiao Hongmen sewage treatment plant, located at Chaoyang District, Beijing. Lime was of analytical reagent grade. RM used in this study was obtained from Shandong Branch, Aluminum Corporation of China, the composition and properties of which were listed in Table 1.

Analytical methods

The $\mathrm{pH}$ and electric conductivity (EC) values of the sewage sludge were measured in slurry at a solid/solution ratio of 1:2.5 in accordance with International Soil Association Method. The moisture content of the sewage sludge was calculated according to the mass difference before and after the sewage sludge being dried in an oven at $105^{\circ} \mathrm{C}$ for $24 \mathrm{~h}$ (Zupancic et al. 2004). Total organic matter was estimated using the loss-on-ignition method (Ben-Dor and Banin 1989). For the measurement of total phosphorus concentration, the sewage sludge was microwave-assisted acid digested according to Walter et al. (1997) and the phosphorus concentration was analyzed by the phosphomolybdate blue method of Murphy and Riley (1962) on a UV/ visible spectrophotometer (DR/4000 HACH, USA) at a wavelength of $700 \mathrm{~nm}$. For the total element analysis, the sewage sludge was digested using concentrated nitric acid, hydrofluoric and perchloric acid according to

Table 1 Composition and properties of RM

\begin{tabular}{ll}
\hline Composition & RM \\
\hline $\mathrm{SiO}_{2} \%(w / w)$ & 12.45 \\
$\mathrm{Fe}_{2} \mathrm{O}_{3} \%(w / w)$ & 25.68 \\
$\mathrm{Al}_{2} \mathrm{O}_{3} \%(w / w)$ & 10.98 \\
$\mathrm{CaO} \%+\mathrm{MgO} \%(\mathrm{w} / \mathrm{w})$ & 13.88 \\
$\mathrm{Na}_{2} \mathrm{O} \%(\mathrm{w} / \mathrm{w})$ & 5.76 \\
$\mathrm{~K}_{2} \mathrm{O} \%(\mathrm{w} / \mathrm{w})$ & 0.33 \\
$\mathrm{TiO}_{2} \%(\mathrm{w} / \mathrm{w})$ & 12.94 \\
$\mathrm{LOI} \%(\mathrm{w} / \mathrm{w})$ & 15.41 \\
$\mathrm{pH}$ & 12.55 \\
$\mathrm{BET}\left(\mathrm{m}^{2} / \mathrm{g}\right)$ & 16.48 \\
$\mathrm{Crystalline} \mathrm{phases}$ & Hematite, Bayerite, \\
& Calcite, Cancrinite, \\
& Goethite, Rutile and Quartz \\
\hline
\end{tabular}


Table 2 Sewage sludge amended with RM, lime, and $\mathrm{RM} /$ lime

\begin{tabular}{llllll}
\hline & Sewage sludge $(\mathrm{g})$ & $\mathrm{RM}(\mathrm{g})$ & Lime $(\mathrm{g})$ & $\mathrm{RM} / \mathrm{lime}(\mathrm{g})$ & DI water $(\mathrm{ml})$ \\
\hline Test A & 3 & 0 & 0 & 0 & 10 \\
Test B & 3 & $0.15,0.3,0.45,0.9$ & 0 & 0 & 10 \\
Test C & 3 & 0 & $0.15,0.3,0.45,0.9$ & 0 & 10 \\
Test D & 3 & 0 & 0 & $0.15,0.3,0.45,0.9$ & 10 \\
\hline
\end{tabular}

Sterckeman et al. (2006), then the total element concentrations were analyzed using an inductively coupled plasma atomic emission spectroscopy (ICP-AES, Prodigy).

Mineralogical constituents of RM were determined using X-ray diffractometry (ShimadzuXRD-6000 Japan). The analysis was performed in a Rikaku TTR-III diffractometer at room temperature, with $\mathrm{Cu} \mathrm{K} \alpha$ radiation at a scan speed range of $0.2 \%$. The XRD patterns were recorded in the $2 \theta$ range of $10^{\circ}-90^{\circ}$. Loss of ignition was determined at $750^{\circ} \mathrm{C}$ in accordance with ASTM D5142-02a (Arthur 2004). The pH of RM was measured in slurry at a solid/water ratio of 1:2.5 in accordance with International Soil Association Method. The specific surface area was determined using the $\mathrm{N}_{2}$ BET method (Micromeritics ASAP2000).

\section{Immobilization experiments}

As for the immobilization experiments, 1,000 $\mathrm{g}$ of sewage sludge samples was thoroughly mixed with amendments in 2,500-ml polypropylene bottles with mass ratios of 5, 10, 15 and $30 \%$. Sewage sludge samples without amendment were also incubated as controls. Un-amended and amended sewage sludge samples were capped and incubated at $25^{\circ} \mathrm{C}$ for 3 days. The $\mathrm{pH}$ values were measured at the completion of the incubation process. After the incubation process was completed, the samples were dried and milled to pass a 0.4$\mathrm{mm}$ sieve and stored in closed dark bottles for further investigation.

\section{Batch leaching experiments}

In order to evaluate the efficiency of RM, lime and RM/ lime for immobilization of phosphorus, un-amended and amended sewage sludge samples were leached with deionized water. Samples and amendments were weighed into 50-ml centrifuge tube. The dosages of samples and amendments were presented in Table 2. Samples and amendments were treated as the above immobilization experiment. At the completion of incubation, samples were agitated for $1 \mathrm{~h}$ with 10-ml de-ionized water; the tubes were then centrifuged at $10,000 \mathrm{rpm}$ for $10 \mathrm{~min}$. Un-filtered samples were collected for measurement of $\mathrm{pH}$ and EC. Filtered samples were collected for measurement of phosphorus concentrations.
Sequential leaching experiments

In order to evaluate the long time immobilization efficiency of each amendment, un-amended and amended sewage sludge samples were subjected to sequential leaching experiments using de-ionized water at a solid/liquid ratio of 1:20. $1 \mathrm{~g}$ of incubated samples and 20-ml de-ionized water were placed in the tubes, capped and agitated on a shaker for $24 \mathrm{~h} \mathrm{at} 25^{\circ} \mathrm{C}$, then centrifuged for $10 \mathrm{~min}$ at $10,000 \mathrm{rpm}$. The supernatants were filtered through 0.45 $\mu \mathrm{m}$ membrane filter and collected for phosphorus analysis. After removal of the supernatants, 20-ml de-ionized water was added to the centrifuge tubes again, the next steps were the same as above. This leaching process was repeated 10 times. The leachate was analyzed by the phosphomolybdate blue method of Murphy and Riley (1962) on a UV/ visible spectrophotometer (DR/4000 HACH, USA) at a wavelength of $700 \mathrm{~nm}$.

\section{Column leaching experiments}

Based on the batch leaching experiment results, a schematic diagram of the columns used for this study is given in Fig. 1. Polyvinyl chloride (PVC) columns with inner diameter of $4.0 \mathrm{~cm}$ and length of $50.0 \mathrm{~cm}$ were used. The samples of the incubated sewage sludge were packed in the columns and the de-ionized water by a pump at a flow ratio of $10 \mathrm{ml} / \mathrm{h}$. Leachates were collected every $24 \mathrm{~h}$ for the measurement of phosphorus concentrations and the leaching experiments lasted for 7 days.

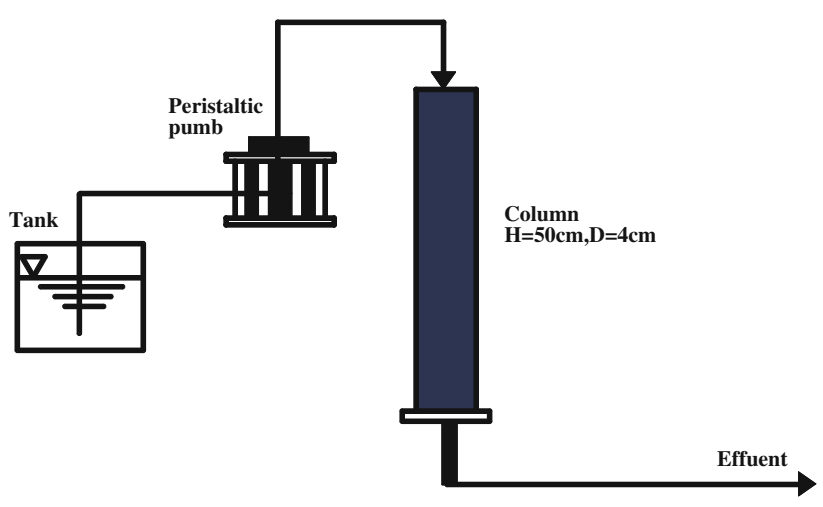

Fig. 1 Schematic layout of a single unit of the experimental columns 
Sequential chemical extraction experiments

In order to analyze phosphorus speciation after immobilization, the incubated samples were also dried at $60^{\circ} \mathrm{C}$ and milled to pass a $0.4-\mathrm{mm}$ sieve. Soil phosphorus was sequentially chemical extracted according to the modified procedure of Hedley's method (1982). A diagrammatic representation of this scheme is given in Fig. 2. The extraction was carried out in 50-ml centrifuge tubes. To each tube, $0.5 \mathrm{~g}$ of incubated sewage sludge was added and sequentially extracted with 30-ml de-ionized water, $0.5 \mathrm{M}$ $\mathrm{NaHCO}_{3}(\mathrm{pH} 8.2), 0.1 \mathrm{M} \mathrm{NaOH}$, and $1.0 \mathrm{M} \mathrm{HCl}$ each for $16 \mathrm{~h}$. After each extraction step, the tubes were centrifuged at $10,000 \mathrm{rpm}$ for $10 \mathrm{~min}$ and the supernatants were filtered through $0.45-\mu \mathrm{m}$ membrane filter. Residual phosphorus was digested with $\mathrm{H}_{2} \mathrm{SO}_{4}-\mathrm{H}_{2} \mathrm{O}_{2}$ by microwave accelerated reaction system (CEM, USA). Total phosphorus was the sum of all above phosphorus. The concentration of phosphorus was analyzed by the phosphomolybdate blue method according to Murphy and Riley (1962) on a UV/ visible spectrophotometer (DR/4000 HACH, USA) at a wavelength of $700 \mathrm{~nm}$.

\section{Results and discussion}

\section{Sewage sludge characteristics}

The main physical and chemical properties of sewage sludge are presented in Table 3 . As shown in the table, the

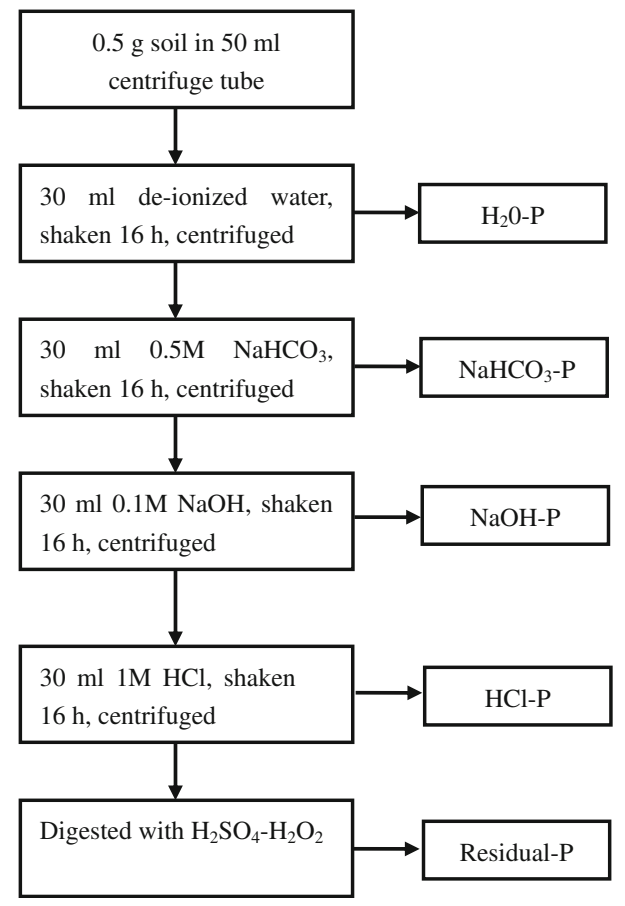

Fig. 2 Sequential chemical extraction scheme
Table 3 Selected properties of the sewage sludge

\begin{tabular}{lc}
\hline Parameter & Sewage sludge \\
\hline $\mathrm{pH}$ & $7.46 \pm 0.18$ \\
$\mathrm{EC}(\mu \mathrm{S} / \mathrm{cm})$ & $1,158 \pm 21$ \\
Moisture content $(\%)$ & $83 \pm 0.90$ \\
Total organic matter $(\mathrm{g} / \mathrm{kg})$ & $497 \pm 0.40$ \\
Total P $(\mathrm{g} / \mathrm{kg})$ & $15.41 \pm 0.17$ \\
$\mathrm{Cu}(\mathrm{mg} / \mathrm{kg})$ & $281 \pm 43$ \\
$\mathrm{Zn}(\mathrm{mg} / \mathrm{kg})$ & $978 \pm 16$ \\
$\mathrm{~K}(\mathrm{mg} / \mathrm{kg})$ & $1,128 \pm 58$ \\
$\mathrm{Na}(\mathrm{mg} / \mathrm{kg})$ & $1,880 \pm 32$ \\
$\mathrm{Fe}(\mathrm{mg} / \mathrm{kg})$ & $4,784 \pm 44$ \\
$\mathrm{Mn}(\mathrm{mg} / \mathrm{kg})$ & $154 \pm 4.00$ \\
\hline
\end{tabular}

$\mathrm{pH}$ and EC values of sewage sludge were $7.46 \pm 0.18$ and $1,158 \pm 24 \mu \mathrm{S} / \mathrm{cm}$, respectively. In addition, sewage sludge presented high moisture content, reaching up to $83.0 \pm 0.90 \%$, while the corresponding total solids consisted of nearly $50 \%$ organic matter and the total organic matter value was $497 \pm 0.40 \mathrm{~g} / \mathrm{kg}$. Furthermore, the total phosphorus content in the sewage sludge was $15.41 \pm$ $0.17 \mathrm{~g} / \mathrm{kg}$, implying that sewage sludge would be a rich source of phosphorus when it was land applied.

Batch leaching experiments

Figure $3 \mathrm{a}$ presents $\mathrm{pH}$ trend of the amended sewage sludge. Treatment effected on $\mathrm{pH}$ varied according to the type of amendments. The $\mathrm{pH}$ values of un-amended and amended sewage sludge are shown in Fig. 3a. It was found that RM, lime and RM/lime amendments all raised the $\mathrm{pH}$ of amended sewage sludge. The $\mathrm{pH}$ value of un-amended sewage sludge was $7.13 \pm 0.05$, whereas the $\mathrm{pH}$ values of $\mathrm{RM}$ amended sewage sludge increased from $8.50 \pm 0.21$ to $11.38 \pm 0.06$. The $\mathrm{pH}$ values of lime and RM/lime amended sewage sludge increased from $12.21 \pm 0.16$ and $8.54 \pm 0.35$ to $12.37 \pm$ 0.02 and $12.25 \pm 0.01$, respectively.

Figure $3 \mathrm{~b}$ presents EC trends of the amended sewage sludge. The EC increased as a result of amendments addition. EC is usually measured because it reflects the salinity of the mixture and its suitability for plant growth. The EC value of un-amended sewage sludge was 1,042 $\pm 68 \mu \mathrm{S} /$ $\mathrm{cm}$, whereas the EC values of RM amended sewage sludge ranged from $2,716 \pm 192$ to $4,077 \pm 63 \mu \mathrm{S} / \mathrm{cm}$. The EC values of lime and RM/lime amended sewage sludge increased from $6,943 \pm 132$ and $3,215 \pm 251 \mu \mathrm{S} / \mathrm{cm}$ to $7,936 \pm 12$ and 7,653 $\pm 164 \mu \mathrm{S} / \mathrm{cm}$, respectively.

There was a general trend of decreasing phosphorus leaching with increasing amendment ratios (Fig. 3c). Phosphorus leached from the un-amended sewage sludge was $237 \pm 22 \mathrm{mg} / \mathrm{kg}$, while phosphorus leached from the 

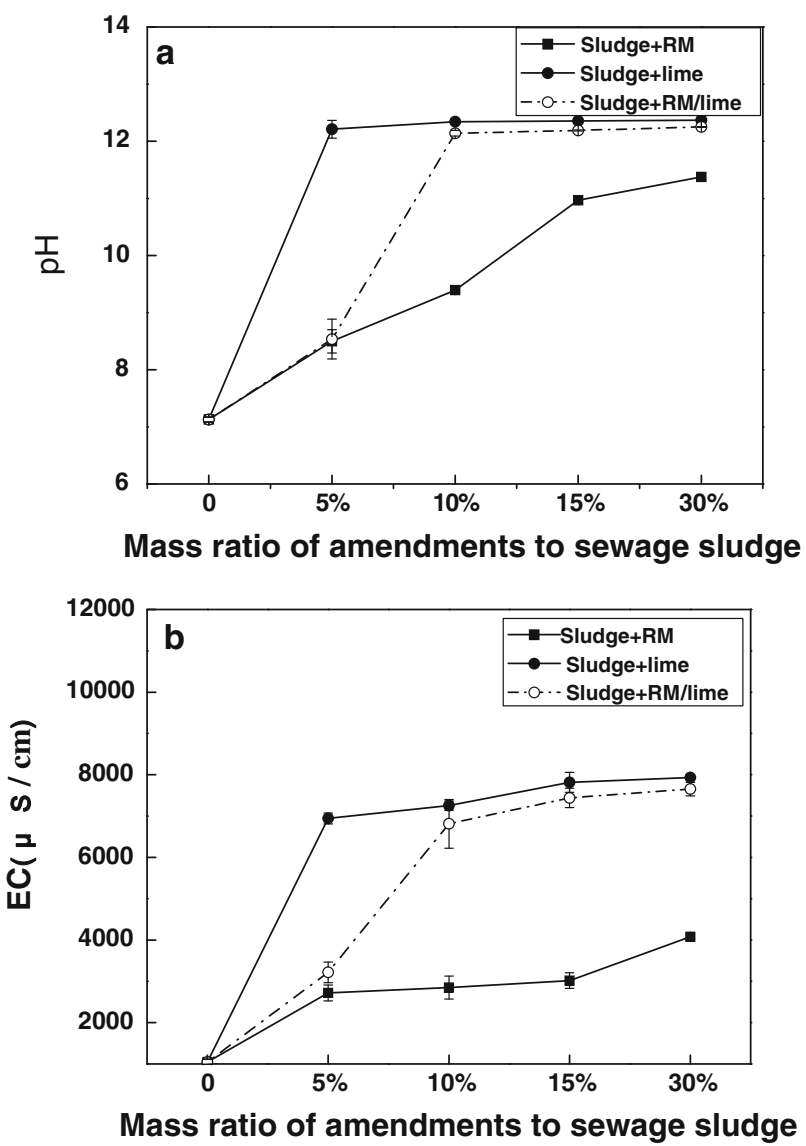

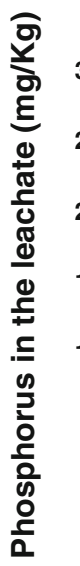

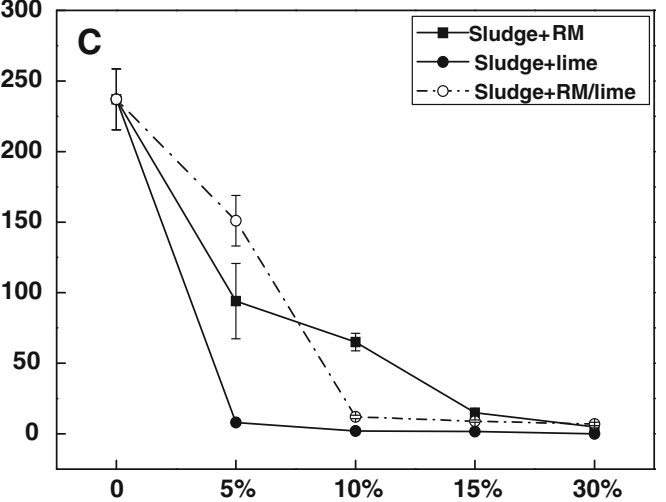

Mass ratio of amendments to sewage sludge

Fig. 3 a pH, b EC, and c phosphorus in the leachates of the unamended and amended sewage sludge

$30 \% \mathrm{RM}$ amended sewage sludge was only $5 \pm 0.8 \mathrm{mg} / \mathrm{kg}$. The reduction in phosphorus leaching from the RM amended sewage sludge is possibly due to the following two reasons. One is that iron and aluminum oxides contained in RM have a high capacity to adsorb phosphorus. The adsorption by the oxides reduced the phosphorus leaching. The other is that phosphorus was precipitated by iron, aluminum and calcium to form stable iron, aluminum and calcium phosphorus compounds.

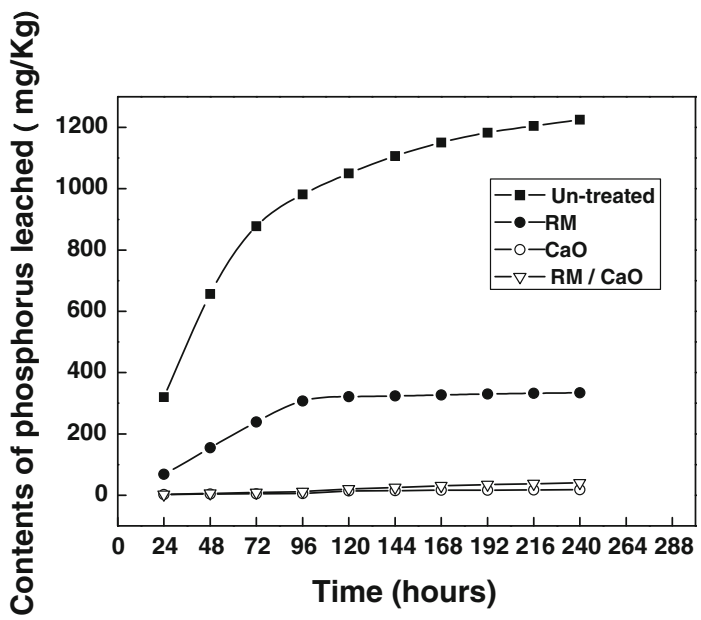

Fig. 4 The cumulative phosphorus leaching as a function of time in un-amended and amended sewage sludge

As did the RM treatment, phosphorus leaching in the lime amended sewage sludge decreased from $237 \pm 22$ to $0 \pm 0 \mathrm{mg} / \mathrm{kg}$. It appears that calcium and $\mathrm{pH}$ are the main factors reducing phosphorus solubility and its leaching in the lime amended sewage sludge. Dou et al. (2003) concluded that $\mathrm{pH}$ above 7.0 and high calcium content was able to immobile phosphorus effectively. The reduction in phosphorus leaching from lime amended sewage sludge is possibly due to precipitation of insoluble Ca-phosphate compounds under alkaline conditions.

Phosphorus leaching from the RM/lime amended sewage sludge decreased from $237 \pm 22$ to $7 \pm 1.2 \mathrm{mg} / \mathrm{kg}$. Both lime and RM/lime amendments can immobilize phosphorus in sewage sludge, but $\mathrm{pH}$ is not within the accepted limit (between 6.5 and 9.5) for plants growth, so from the agricultural view, RM would be a better choice for immobilization of phosphorus.

\section{Sequential leaching experiments}

Phosphorus leaching from the un-amended and amended sewage sludge as a function of leaching time is shown in Fig. 4. The amount of phosphorus leaching from unamended and amended sewage sludge decreased with sequential leaching. As expected, compared with the unamended sewage sludge sample, amended sewage sludge samples leached significantly less phosphorus. When sewage sludge was amended with 10\% RM, lime and RM/ lime, the cumulative amount of phosphorus leaching was reduced from 1,225 to 333,18 and $40 \mathrm{mg} / \mathrm{kg}$, respectively.

The mechanism by which the cumulative phosphorus leaching is reduced maybe was the result of precipitation and adsorption reactions represented by the following possible reactions: 


$$
\begin{aligned}
& x \mathrm{Fe}^{3+}+z \mathrm{H}_{n} \mathrm{PO}_{4}{ }^{n-3}+(y+n z) \mathrm{OH}^{-} \rightarrow \mathrm{Fe}_{x}(\mathrm{OH})_{y}\left(\mathrm{PO}_{4}\right)_{z} \\
& \quad \downarrow+n z \mathrm{H}_{2} \mathrm{O} \\
& 2 \mathrm{Al}^{3+}+2 \mathrm{H}_{3} \mathrm{PO}_{4} \rightarrow 2 \mathrm{AlPO}_{4}+6 \mathrm{H}^{+} \\
& \mathrm{Al}(\mathrm{OH})_{3}+\mathrm{H}_{3} \mathrm{PO}_{4} \rightarrow \mathrm{Al}(\mathrm{OH})_{3}-\mathrm{H}_{3} \mathrm{PO}_{4} \\
& 3 \mathrm{Ca}^{2+}+2 \mathrm{H}_{2} \mathrm{PO}_{4}{ }^{-}+4 \mathrm{OH}^{-} \rightarrow \mathrm{Ca}_{3}\left(\mathrm{PO}_{4}\right)_{2} \downarrow+4 \mathrm{H}_{2} \mathrm{O} \\
& 3 \mathrm{Ca}^{2+}+2 \mathrm{HPO}_{4}{ }^{2-}+2 \mathrm{OH}^{-} \rightarrow \mathrm{Ca}_{3}\left(\mathrm{PO}_{4}\right)_{2} \downarrow+2 \mathrm{H}_{2} \mathrm{O} \\
& 3 \mathrm{Ca}^{2+}+2 \mathrm{PO}_{4}{ }^{3-}+2 \mathrm{OH}^{-} \rightarrow \mathrm{Ca}_{3}\left(\mathrm{PO}_{4}\right)_{2} \downarrow
\end{aligned}
$$

Column leaching experiments

A column leaching test was set up to evaluate the phosphorus leaching from the amended sewage sludge for land application. Phosphorus concentrations in the leachate of un-amended and amended sewage sludge columns are presented in Fig. 5. Phosphorus concentrations in the leachate of the un-amended and amended sewage sludge decreased over time as the more soluble forms of the phosphorus were flushed out of the columns. Phosphorus concentrations in the leachate from the amended sewage sludge columns were less than that in the leachate from the un-amended sewage sludge column. After 7-day continuous leaching, phosphorus concentration in the leachate from un-amended sewage sludge decreased to $2.47 \mathrm{mg} / \mathrm{l}$, while phosphorus concentrations in the leachate from RM, lime and RM/lime amended sewage sludge decreased to $0.88,0.50,0.82 \mathrm{mg} / \mathrm{l}$, respectively. These results show that $\mathrm{RM}$, lime and RM/lime had a high capacity for the immobilization of phosphorus.

Sequential chemical extraction experiments

To identify the changes of phosphorus speciation resulted from the amendments added, the un-amended and

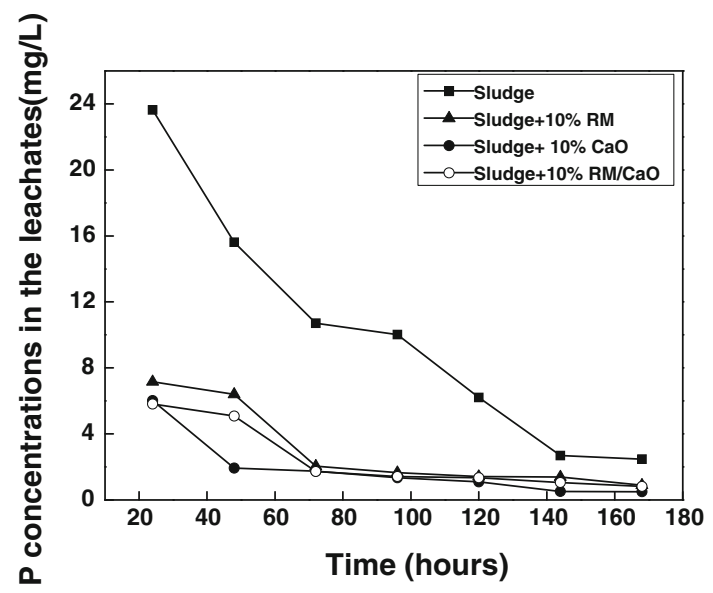

Fig. 5 Phosphorus concentrations in the leachate from the unamended and amended sewage sludge amended sewage sludge were analyzed by sequential chemical extraction experiments. This method provided useful information for explaining the immobilization of phosphorus. This information is useful to predict the transport of phosphorus in soil as well as to predict the likelihood of its bioavailability. The main phosphorus speciation was $\mathrm{H}_{2} \mathrm{O}-\mathrm{P}, \mathrm{NaHCO}_{3}-\mathrm{P}, \mathrm{NaOH}-\mathrm{P}, \mathrm{HCl}-\mathrm{P}$ and Residual-P. Among them, $\mathrm{H}_{2} \mathrm{O}-\mathrm{P}$ is designated as loosely bound phosphorus, the sum of loosely bound phosphorus and $\mathrm{NaHCO}_{3}-\mathrm{P}$ is designated as labile phosphorus (Huang et al. 2008b). In the un-amended sewage sludge, the percentage of the loosely bound phosphorus and labile phosphorus was 3.35 and $19.41 \%$, respectively. The large amounts of these fractions indicate that phosphorus in the un-amended sewage sludge is easy to leach and is available to plants. All immobilization procedures changed the phosphorus concentration and distribution among fractions. There was an apparent trend of total phosphorus decrease with increasing amendments addition. This trend is partially explained by dilution and does not necessarily reflect the immobilization process. To better evaluate phosphorus immobilization process, the relative phosphorus distribution among fractions in Fig. 6 was discussed next.

In un-amended sewage sludge sample, the percentage of $\mathrm{H}_{2} \mathrm{O}-\mathrm{P}, \mathrm{NaHCO}_{3}-\mathrm{P}, \mathrm{NaOH}-\mathrm{P}$ and $\mathrm{HCl}-\mathrm{P}$ was $3.35,16.06$, 37.36 and $18.11 \%$, respectively. After RM immobilization, the phosphorus distribution among fractions changed. The percentage of $\mathrm{H}_{2} \mathrm{O}-\mathrm{P}$ and $\mathrm{HCl}-\mathrm{P}$ decreased from 3.35 and $18.11 \%$ to 1.42 and $5.28 \%$, respectively, whereas the percentage of NaOH-P increased from 37.36 to $51.10 \%$. The $\mathrm{NaOH}-\mathrm{P}$ fraction is considered to be amorphous and crystalline $\mathrm{Fe}$ and $\mathrm{Al}$ phosphates (Hedley et al. 1982; Sharpley 1996). The above results indicate that loosely bound phosphorus was retained by absorption to newly formed $\mathrm{Fe}$ and $\mathrm{Al}$ hydroxides, while transformed $\mathrm{H}_{2} \mathrm{O}-\mathrm{P}$

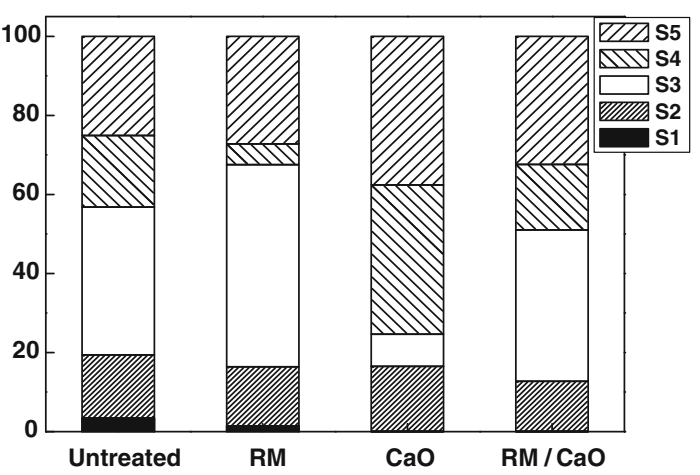

Fig. 6 Phosphorus speciation in the un-amended and amended sewage sludge. $S 1 \mathrm{H}_{2} \mathrm{O}-\mathrm{P}, \mathrm{S} 2 \mathrm{NaHCO}_{3}-\mathrm{P}, S 3 \mathrm{NaOH}-\mathrm{P}, \mathrm{S} 4 \mathrm{HCl}-\mathrm{P}$, S5 Residual-P 
into $\mathrm{NaOH}-\mathrm{P}$. Huang et al. (2008b) observed the similar result when the sewage sludge was amended with material containing $\mathrm{Fe}$ and $\mathrm{Al}$ elements. In the $10 \%$ lime amended sewage sludge, the percentage of $\mathrm{H}_{2} \mathrm{O}-\mathrm{P}$ and $\mathrm{NaOH}-\mathrm{P}$ decreased from 3.35 and $37.36 \%$ to 0.036 and $8.18 \%$, respectively, whereas the percentage of $\mathrm{HCl}-\mathrm{P}$ increased from 18.11 to $37.70 \%$. The $\mathrm{HCl}-\mathrm{P}$ fraction is considered to be calcium phosphate. These phosphorus distribution changes indicate that loosely bound phosphorus and $\mathrm{Fe}$ and Al phosphate were transformed to calcium phosphate by addition of lime. Similar result has been reported by Huang and Shenker (2004), who confirmed this transformation by SEM-EDXS. In the $10 \% \mathrm{RM} /$ lime amended sewage sludge sample, the percentage of $\mathrm{H}_{2} \mathrm{O}-\mathrm{P}, \mathrm{NaHCO}_{3}-\mathrm{P}, \mathrm{NaOH}-\mathrm{P}$ and $\mathrm{HCl}-\mathrm{P}$ was $0.055,12.70,38.28$ and $16.58 \%$, respectively.

From the results obtained, it indicates that all amendments significantly changed the phosphorus speciation in the amended sewage sludge and transformed $\mathrm{H}_{2} \mathrm{O}-\mathrm{P}$ into more stable fractions.

\section{Conclusion}

1. RM, lime and RM/lime amendments were successfully used for immobilization of phosphorus in sewage sludge. But $\mathrm{pH}$ of lime and RM/lime amended sewage sludge is not within the accepted limit (between 6.5 and 9.5) for plants growth. So from the agricultural view, RM would be a better choice for immobilization of phosphorus.

2. Phosphorus leaching from RM amended sewage sludge was reduced due to iron and aluminum oxides contained in RM that have a high capacity to adsorb phosphorus and phosphorus was precipitated by iron, aluminum and calcium to form stable iron, aluminum and calcium phosphorus compounds, while phosphorus leaching from the lime amended sewage sludge was reduced only due to precipitation of insoluble calcium phosphorus compound under alkaline conditions.

3. Sequential chemical extraction experiments showed that red mud amendment transformed $\mathrm{H}_{2} \mathrm{O}-\mathrm{P}$ in the sewage sludge into the $\mathrm{NaOH}-\mathrm{P}$, while the lime amendment transformed $\mathrm{H}_{2} \mathrm{O}-\mathrm{P}$ in the sewage sludge into the HCl-P.

Acknowledgments Financial support provided by Public Industry Research for National Environmental Protection (under Grant No. 200709037), the Water Pollution Control and Management Project (under Grant No. 2009ZX07104-005) and the National High Technology R\&D Program (863) from Ministry of Science \& Technology of China (under Grant No. 2007AA06Z344 and Grant No. 2008AA06A409-3) was gratefully acknowledged. The provision of red mud by Research Institute of Shandong Branch, Aluminum Corporation of China was greatly appreciated.

\section{References}

Anderson DL, Tuovinen OH, Faber A, Ostrokowski I (1995) Use of soil amendments to reduce soluble phosphorus in dairy soils. Ecol Eng 5:229-246

Arthur DS (2004) Annual book of ASTM standards. ASTM Intl, USA

Ben-Dor E, Banin A (1989) Determination of organic matter content in arid-zone soils using a simple "loss-on-ignition" method. Commun Soil Sci Plant Anal 20:1675-1695

Clapp CE, Larson WE, Dowdy RH (1994) Sewage sludge: land utilization and the environment. SSSA Miscellaneous Publication, Madison

Correll DL (1998) The role of phosphorus in the eutrophication of receiving water: a review. J Environ Qual 27:261-266

Dou Z, Zhang GY, Stout WL, Toth JD, Ferguson JD (2003) Efficacy of alum and coal combustion by-products in stabilizing manure phosphorus. J Environ Qual 32:1490-1497

Hedley MJ, Stewart JWB, Chauhan BS (1982) Changes in inorganic and organic soil phosphorus fractions by cultivation practice and by laboratory incubations. Soil Sci Soc Am J 46:970-976

Ho GE, Mathew K, Newman PWG (1989) Leachate quality from gypsum neutralized red mud applied to sandy soils. Water Air Soil Pollut 47:1-18

Huang XL, Shenker M (2004) Water-soluble and solid-state speciation of phosphorus in stabilized sewage sludge. J Environ Qual 33:1895-1903

Huang XL, Chen Y, Shenker M (2007) Solid phosphorus phase in aluminum- and iron-treated biosolids. J Environ Qual 36:549-556

Huang WW, Wang SB, Zhu ZH, Li L, Yao XD, Rudolph V, Haghseresht F (2008a) Phosphate removal from wastewater using red mud. J Hazard Mater 158:35-42

Huang XL, Chen Y, Shenker M (2008b) Chemical fractionation of phosphorus in stabilized biosolids. J Environ Qual 37:1949-1958

Ippolito JA, Barbarick KA, Heil DM, Chandler JP, Redente EF (2003) Phosphorus retention mechanisms of a water treatment residual. J Environ Qual 32:1857-1864

Kalbasi M, Karthikeyan KG (2004) Phosphorus dynamics in soils receiving chemically treated dairy manure. J Environ Qual 33:2296-2305

Lee DJ, Spinosa L, He PJ, Chen TB (2006) Sludge production and management processes case study in China. Water Sci Technol 54:189-196

Li YZ, Liu CJ, Luan ZK, Peng XJ, Zhu CL, Chen ZY, Zhang ZG, Fang JH, Jia ZP (2006) Phosphorus removal from aqueous solutions using raw and activated red mud and fly ash. J Hazard Mater 137(1):374-383

Li XQ, Derick G, Brown, Zhang WX (2007) Stabilization of biosolids with nanoscale zero-valent iron (nZVI). J Nanopart Res 9:233-243

Liu CJ, Li YZ, Luan ZK, Chen ZY, Zhang ZG, Jia ZP (2007) Adsorption removal of phosphate from aqueous solution by active red mud. J Environ Sci China 19:1166-1170

Logan TJ, Burnham JC (1995a) Physical characteristics of alkaline stabilized sewage sludge (N-Viro soil) and their effects on soil physical properties. J Environ Qual 24:153-164

Logan TJ, Burnham JC (1995b) The alkaline stabilization with accelerated drying process ( $\mathrm{N}$-Viro): an advanced technology to convert sewage sludge into a soil product. American Society of Agronomy Publications, Madison

Mahdy AM, Elkhatib EA, Fathi NO, Lin ZQ (2009) Effect of coapplication of biosolids and water treatment residuals on corn growth and bioavailable phosphorus and aluminum in alkaline soils in Egypt. J Environ Qual 38:1501-1510

Matthews PJ (1992) Sewage sludge disposal in the UK: a new challenge for the next twenty years. Water Environ J 6:551-559 
McPharlin IR, Jeffery RC, Toussaint LF, Cooper M (1994) Phosphorus, nitrogen, and radionuclide retention and leaching from a Joel sand amended with red mud/gypsum. Commun Soil Sci Plan 25:2925-2944

Moore PA Jr, Miller DM (1994) Decreasing phosphorus solubility in poultry litter with aluminum, calcium, and iron amendments. J Environ Qual 23:325-330

Murphy J, Riley JP (1962) A modified single solution method for the determination of phosphate in natural waters. Anal Chim Acta 27:31-36

O'Connor GA, Shaker D, Briton SR, Elliott HA, Martin FG (2004) Phytoavailability of biosolids phosphorus. J Environ Qual 33:703-712

Peterson AE, Speth PE, Corey RB, Wright TW, Schlecht PL (1994) Effect of twelve years of liquid sludge application on soil phosphorus level. SSSA Miscellaneous Publication, Madison

Roberge G, Blais JF, Mercier G (1999) Phosphorus removal from wastewater treated with red mud-doped peat. Can J Chem Eng 77:1185-1194

Sharpley AN (1996) Availability of residual phosphorus in manured soils. Soil Sci Soc Am J 60:1459-1466

Sterckeman T, Ciesielski H, Gomez A (2006) Soil and waste analysis for environmental risk assessment in France. Sci Total Environ 178:63-69

Stout WL, Sharpley AN, Landa J (2000) Effectiveness of coal combustion by-products in controlling phosphorus export from soils. J Environ Qual 29:1239-1244

Summers RN, Guise NR, Smirk DD (1993) Bauxite residue (red mud) increases phosphorus retention in sandy soil catchments in Western Australia. Fertil Res 34:85-94
Summers RN, Smirk DD, Karafilis D (1996a) Phosphorus retention and leachates from sandy soil amended with bauxite residue (red mud). Aust J Soil Res 34:555-567

Summers RN, Guise NR, Smirk DD, Summers KJ (1996b) Bauxite residue (red mud) improves pasture growth on sandy soils in Western Australia. Aust J Soil Res 34:569-581

Udeigwe TK, Wang JJ, Zhang HL (2009) Effectiveness of bauxite residues in immobilizing contaminants in manure-amended soils. Soil Sci 174:676-686

Vlahos S, Summers KJ, Bell DT, Gilkes RJ (1989) Reducing phosphorus leaching from sandy soils with red mud bauxite processing residues. Aust J Soil Res 27:651-662

Walter PJ, Chalk S, Kingston HM (1997) Overview of micro-waveassisted sample preparation. Am Chem Soc, Washington, DC

Wang W, Luo YX, Qiao W (2010) Possible solutions for sludge dewatering in China. Front Environ Sci Eng China 4:102-107

Zhao Y, Wang J, Luan ZK, Peng XJ, Liang Z, Shi L (2009) Removal of phosphate from aqueous solution by red mud using a factorial design. J Hazard Mater 165:1193-1199

Zheng GD, Gao D, Chen TB, Luo W (2006) Stabilization of nickel and chromium in sewage sludge during aerobic composting. J Hazard Mater 142:216-221

Zupancic M, Bukovec N, Milacic R, Scancar J (2004) Comparison of various phosphate stabilization agents for the immobilization of Ni and Zn in sewage sludge. Water Air Soil Poll 156:57-69 